\title{
IDENTIFIKASI KEPATUHAN PENDOKUMENTASIAN ASUHAN KEPERAWATAN DI RUANG RAWAT INAP RSU B
}

\section{IDENTIFICATION OF COMPLIANCE WITH NURSING CARE DOCUMENTATION IN THE INPATIENT ROOM $R S U B$}

\author{
Nurul Faidah', Ni Komang Ayu Resiyanthi \\ ${ }^{1}$ Rekam Medis Dan Informasi Kesehatan, Sekolah Tinggi Ilmu Kesehatan Wira Medika Bali \\ Ners (Profesi), Sekolah Tinggi Ilmu Kesehatan Wira Medika Bali
}

\begin{abstract}
ABSTRAK
Kepatuhan dalam pendokumentasian keperawatan merupakan aspek legal dalam keperawatan. Dokumentasi Asuhan Keperawatan terdiri dari pengkajian, diagnosa keperawatan, intervensi dan evaluasi. Dokumentasi memegang peranan penting terhadap segala macam tuntutan dan merupakan satu bentuk upaya membina serta mempertahankan akuntabilitas perawat dan keperawatan. Tujuan penelitian ini untuk mengetahui kepatuhan pendokumentasian asuhan keperawatan di ruang rawat inap RSU B. Metode yang digunakan crossectional jumlah sampel dalam penelitian ini sebanyak 33 orang. Dalam penelitian ini analisis data deskriptif. Dengan hasil penelitian jenis kelamin perempuan $60,6 \%$, usia $69,7 \%>35$ tahun, pendidikan 63,6\% DIII Keperawatan, masa kerja $60.6 \%$ lebih dari 3 tahun dan hasil dari kepatuhan pendokumentasian asuhan keperawatan 63,6\% patuh. Peneliti menyarankan untuk pelayanan kesehatan meningkatkan pengetahuan perawat dengan memberikan workshop atau pelatihan pendokumentasian asuhan keperawatan untuk meningkatkan kepatuhan perawat dalam dokumentasi asuhan keperawatan.
\end{abstract}

Kata kunci: Kepatuhan dokumentasi keperawatan, Perawat.

\section{ABSTRACT}

Compliance with nursing documentation is a legal aspect of nursing. Nursing Care Documentation consists of assessment, nursing diagnoses, interventions and evaluations. Documentation plays an important role in all kinds of demands and is a form of effort to foster and maintain nurse and nursing accountability. The purpose of this study was to determine the compliance of nursing care documentation in the inpatient ward of RSU B. The method used was cross-sectional number of samples in this study as many as 33 people. In this research descriptive data analysis. With the results of the study of female gender $60.6 \%$, age $69.7 \%>35$ years, education $63.6 \%$ Nursing, $60.6 \%$ work period of more than 3 years and the results of compliance documenting nursing care $63.6 \%$ obedient. Researchers suggest that health services increase nurses' knowledge by providing workshops or training in documenting nursing care to improve nurse compliance in nursing care documentation.

Balimedikajurnal.com 
BMJ. Vol 6 No 2, 2019: 130-135

ISSN : 2615-7047

DOI: $\underline{\text { https://doi.org/10.36376/bmj.v6i2 }}$

Keyword: Compliance with nursing documentation, Nurse.

\begin{tabular}{ll}
\hline Alamat Korespondensi & $\begin{array}{l}\text { : STIKes Wira Medika Bali Jln. Kecak No. 9A Gatot Subroto Timur } \\
\text { Denpasar }\end{array}$ \\
Email & nurulfaidah_wika@yahoo.co.id \\
\hline
\end{tabular}

\section{PENDAHULUAN}

Dokumentasi asuhan keperawatan adalah pencatatan setiap kegiatan asuhan keperawatan yang di berikan oleh perawat kepada pasien. Dokumentasi Asuhan Keperawatan terdiri dari pengkajian, diagnosa keperawatan, intervensi dan evaluasi. Asuhan keperawatan (Nursing Services) yang di lakukan perawat dengan menggunakan pendekatan proses keperawatan (Nursing Process) dapat terlihat dari hasil dokumentasi keperawatan. Kaitannya dengan keperawatan, maka dokumentasi memegang peranan penting terhadap segala macam tuntutan dan merupakan satu bentuk upaya membina serta mempertahankan akuntabilitas perawat dan keperawatan. Untuk mempertahankan akuntabilitas keperawatan perlu meningkatkan kepatuhan pendokumentasian. Meningkatkan kepatuhan perawat dalam melakukan dokumentasi keperawatan dilihat dari indikator tingkat pengetahuan perawat terkait dengan kepatuhan dalam melakukan dokumentasi. Tugas pokok perawat menurut Peraturan Menteri Kesehatan Nomor 148 tahun 2010 adalah melakukan kegiatan pelayanan keperawatan yang meliputi asuhan keperawatan. Seorang perawat harus mampu melaksanakan asuhan keperawatan sesuai standar, yaitu mulai dari pengkajian sampai dengan evaluasi dalam upaya meningkatkan mutu pelayanan kesehatan (Nursalam, 2008). Dengan peningkatan beban kerja akan keterkaitan dengan kepatuhan perawat dalam melakukan pendokumentasian. Kepatuhan perawat dalam penerapan standar pelayanan keperawatan dan standar prosedur operasional sebagai salah satu ukuran keberhasilan pelayanan keperawatan. Kepatuhan dalam dokumentasi keperawatan merupakan tolak ukur dari keberhasilan tenaga kesehatan terutama keperawatan bukan hanya merawat pasien saja sebagai kegiatan langsung, tetapi juga kegiatan tidak langsung yang tidak kalah penting yaitu seperti melengkapi dan melaksanakan dokumentasi asuhan keperawatan dan catatan medik yang terperinci (Mustini, 2013). Berdasarkan penelitian yang dilakukan oleh Putri, 2015 diperoleh perawat melaksanakan dokumentasi secara tidak lengkap dan yang mempunyai beban kerja ringan sebesar $34,5 \%$. Berdasarkan studi pendahuluan yang di lakukan di ruang rawat inap dari 10 rekam medik pasien di RSU B untuk kepatuhan dokumentasi pengkajian 50\%, diagnosa keperawatan 93\%, intervensi keperawatan 81,6\%, implementasi $82,5 \%$, evaluasi $95 \%$, untuk catatan asuhan keperawatan sebesar $68 \%$. Hal ini menunjukkan bahwa kepatuhan pendokumentasian keperawatan belum mencapai target yang di harapkan berdasarkan standar departemen kesehatan kepatuhan perawatan dalam pendokumentasian adalah 95\%. Untuk pengetahuan perawat dari 10 perawat di peroleh 8 perawat pengetahuan cukup, 1 perawat baik, 1 perawat kurang.untuk beban kerja perawat dari 10 orang itu adalah beban kerja ringan. berdasarkan masalah diatas peneliti tertarik mengambil judul "Identifikasi Kepatuhan pendokumentasian Asuhan Keperawatan Di Ruang Rawat Inap Di RSU

Balimedikajurnal.com 
B". Tujuan dalam penelitian ini untuk mnegetahui jumlah kepatuhan dokumentasi asuhan keperawatan.

\section{METODE PENELITIAN}

Jenis penelitian ini adalah penelitian kuantitatif non-eksperimen dengan desain penelitian korelasional. Teknik yang digunakan crosssectional.. Jumlah dokumen dalam penelitian ini yaitu 33 perawat diruang rawat inap. Penelitian ini dilakukan di ruang rawat inap RSU B Denpasar. variabel dalam penelitian ini adalah kepatuhan dalam pendokumentasian asuhan keperawatan. Pengumpulan data dalam penelitian diambil data sekunder mengambil rekam medik pasien. denga melihat kelengakapan isi dari pendokumentasian asuhan keerawatan di dalamnya terdiri dari mulai pengkajian, diagnosa, intervensi, implementasi dan evaluasi dengan kriteria penilaian pengetahuan perawat terkait dokumentasi keperawatan dengan skor $76 \%$ - 100\% kategori baik, kemudian 56\% - 75\% cukup dan $<56 \%$ kurang. Untuk data keptuhan dokumentasi asuhan keperawatan peneliti menggunakan data sekunder yaitu melihat rekam medik pasien yang baru keluar dari rumah sakit dan mengecek rekam medik yang diisi oleh responden. dalam penelitian ini maka uji statistik univariat.

\section{Hasil Penelitian}

\section{HASIL DAN PEMBAHASAN}

a. Karakteristik subyek penelitian

Tabel 1

Distribusi Frekuensi umur, jenis kelamin, pendidikan dan masa kerja responden

\begin{tabular}{ccc}
\hline Umur & Frekuensi (f) & Persentase (\%) \\
\hline$<35 \mathrm{Th}$ & 10 & 30,3 \\
$\geq 35 \mathrm{Th}$ & 23 & 69,7 \\
\hline Jenis kelamin & Frekuensi (f) & Persentase (\%) \\
\hline Laki-laki & 13 & 39,4 \\
\hline Perempuan & 20 & 60,6 \\
\hline Tingkat Pendidikan & Frekuensi (f) & Persentase (\%) \\
\hline DIII Keperawatan & 21 & 63,6 \\
\hline S1/S1 Ners Keperawatan & 12 & 36,4 \\
\hline Masa Kerja & Frekuensi (f) & Persentase (\%) \\
\hline$<3$ tahun & 13 & 39,4 \\
\hline$\geq 3$ tahun & 20 & 60,6 \\
\hline Total & 33 & 100
\end{tabular}

Berdasarkan Tabel 1 diperoleh hasil untuk umur responden sebgaian besar $\geq$ 35 Th 23 (69,7\%), untuk jenis kelamin perempuan 20 (60,6\%), tingkat pendidikan DIII Keperawatan 21(63,6\%) sedangkan untuk masa kerja $\geq 3$ tahun $20(60,6 \%)$. 
BMJ. Vol 6 No 2, 2019: 130-135

ISSN : $2615-7047$

DOI: https://doi.org/10.36376/bmj.v6i2

Tabel 2

Distribusi Frekuensi Kepatuhan Pendokumentasian Keperawatan di Ruangan Rawat Inap RSU B Tahun 2018

\begin{tabular}{ccc}
\hline $\begin{array}{c}\text { Kepatuhan } \\
\text { Pendokumentasian }\end{array}$ & Frekuensi (f) & Persentase (\%) \\
\hline Tidak Patuh & 12 & 36,4 \\
Patuh & 21 & 63,6 \\
\hline Jumlah & 33 & 100 \\
\hline
\end{tabular}

Berdasarakan Tabel diatas diperoleh hasil Kepatuhan Pendokumentasian asuhan keperawatan $21(63,6)$ Patuh dalam pendokumentasian asuhan keperawatan.

\section{Pembahasan}

Berdasarkan hasil dari penelitian sebagian besar perawat patuh $21(63,6 \%)$ dalam melakukan pendokumentasian asuhan keperawatan. Penelitian ini sejalan penelitian yang dilakukan oleh Citra (2010) hasil penelitian kepatuhan dokumentasi keperawatan dari pengkajian diperoleh tidak patuh 5,3\%, dan patuh $94,7 \%$ dan dari evaluasi keperawatan diperoleh 10,5\% tidak patuh, $89,5 \%$ patuh. Kepatuhan perawat dalam pendokumentasian asuhan keperawatan bermanfaat untuk meningkatkan aspek legalitas keperawatan. Dokumentasi asuhan keperawatan bermanfaat sebagai media komunikasi antara perawat satu dengan perawat yang lain. Dokumentasi keperawatan merupakan kegiatan pelayanan keperawatan yang telah dilaksanakan oleh seseorang perawat profesional dapat dipertanggung jawabkan dalam upaya peningkatan mutu pelayanan keperawatan, pelayanan kesehatan dan perbaikan status kesehatan pasien. Kepatuhan dokumentasi asuhan keperawatan dari ke lima komponen itu dalam penelitian ini diperoleh hasil sebagian besar patuh dalam pendokumentasian asuhan keperawatan. Pengkajian yang di ketahui oleh perawat yaitu komponen dalam pengkajian yang meliputi Pengkajian keperawatan meliputi informasi biografi, harapan klien, riwayat kesehatan, spiritual, psikososial dan pemeriksaan fisik untuk menegakkan diagnosa keperawatan setelah melakukan pengkajian dengan lengkap (Potter \& Perry, 2010). Selain terkait dengan pengetahuan pengkajian langkah selanjutnya yaitu tentang diagnosa keperawatan setelah melakukan pengkajian, Diagnosa keperawatan dibagi menjadi diagnosa aktual, risiko, potensial, promosi kesehatan dan kesejahteraan (Potter \& Perry, 2010). Diagnosa keperawatan aktual terdiri dari komponen problem (masalah), etiologi dan symptom, untuk diagnosa keperawatan risiko komponennya adalah masalah dan faktor risiko dan untuk diagnosa promosi kesehatan terdiri dari problem dan symptom (PPNI, 2016).

Hasil penelitian ini menunjukan Kesimpulan dalam penelitian ini diperoleh bahwa kepatuhan oerawat dalam melakukan dokumentasi asuhan keperawatan masih bagus tetapi perlu ditingkatkan lagi untuk Dokumentasi asuhan keperawatan merupakan bagian integral dari asuhan keperawatan yang dilaksanakan sesuai standar. Dengan demikian pemahaman, ketrampilan dalam menerapkan standar dengan baik merupakan suatu hal yang mutlak bagi setiap tenaga keperawatan agar mampu membuat dokumentasi keperawatan secara baik dan benar (Perry, 2010). Dokumentasi mempunyai beberapa tujuan, manfaat dan tahapan tahapan dalam 
DOI: $\underline{\text { https://doi.org/10.36376/bmj.v6i2 }}$

proses asuhan keperawatan, antara lain mengidentifikasi status kesehatan klien dalam mencatat kebutuhan klien, dokumentasi sebagai penelitian, keuangan, hukum dan etika serta sebagai bukti kualitas asuhan keperawatan dan bukti legal. Dokumentasi asuhan keperawatan terdiri dari pengkajian, diagnosa keperawatan, intervensi, imlemnetasi dan evaluasi. Setiap tahap diatas harus dilengkapi oleh perawat dikarenakan dokumnetasi asuhan keperawatan merupakan aspek legal etik keperawatan.

Kepatuhan dokumentasi asuhan kepeaerawatan dari ke lima komponen itu dalam penelitian ini diperoleh hasil sebagian besar patuh dalam pendokumentasian asuhan keperawatan. Adapun beberapa faktor mempengaruhinya adalah pengetahuan, beban kerja, kondisi kerja, reward yang dalam penelitian sebagian besar pengetahuan tentang dokumentasi asuhan keperawatan dalam kategori cukup sehingga berkaitan dengan kepatuhan dalam pendokumentasian asuhan kepearawatan, karena dengan pengetahuan yang cukup perawat meningkatkan kepatuhan dalam dokumentasi karena sudah memahami manfaat dari dokumentasi asuhan keperawatan. Selain itu beban kerja dan kondisi kerja juga mempengaruhi perawat dalam meningkatkan kepatuhan pendokumentasian asuhan keperawatan

Keterbatasan dalam penelitian yaitu Metode yang digunakan dalam penelitian menggunakan data sekunder untuk melihatn kepatuhan dalam pendokumentasian asuhan keperawatan, yang seharusnya perawat bisa dilakukan observasi pada saat melaukan dokumentasi asuhan keperawatan.

\section{SIMPULAN DAN SARAN}

Hasil penelitian di dapatkan sebagian besar tingkat pendidikan perawat adalah $63,3 \%$,jenis kelamin perempuan $60,6 \%$, usia $69,7 \%>35$ thn, masa kerja $60,6 \%>3$ th. Sebagian besar kepatuhan pendokumentasian di ruang rawat inap rumah sakit umum "B" kategori patuh $(63,6 \%)$.

\section{UCAPAN TERIMAKASIH}

Ucapan terimakasih peneliti sampaikan kepada Ketua STIKes Wira Medika Bali, Ketua Program studi, enumerator penelitian dan RS B yang telah memberikan ijin untuk mengambil data.

\section{DAFTAR PUSTAKA}

1. Azis, Alimul. 2005. pengantar konsep dasar keperwatan. jakarta: salemba medika.

2. Azwar, S. 2009. Sikap manusia, Teori dan pengukurannya. jakarta: Pustaka pelajar.

3. Citra, E. 2010. Analisis kepatuhan perawat pada standar asuhan keperawatan di unit rawat inap kelas III RSU PKU Muhammadiyah bantul Yogyakarta tahun 2010.tesis

4. Lapau, Buchori. 2013. Metode Penelitian Kesehatan.Jakarta: Yayasan pustaka Obor Indonesia 
DOI: https://doi.org/10.36376/bmj.v6i2

5. Labora, S. 2015. Deskripsi tingkat kepatuhan perawat pelaksana melakukan dokumentasi asuhan keperawatan di ruang rawat " $K$ " $R S$ PGI Cikini tahun 2015.tesis

6. Mastini, Putri. 2015. Hubungan tingkat pengetahuan, Sikap, Beban kerja perawat dengan kelengkapan Dokumentasi Asuhan keperawatan di IRNA IGD RSUP Sanglah Denpasar.tesis

7. Notoadmojo. 2010. Ilmu Perilaku Kesehatan. jakarta: Rineka Cipta.

8. Pribadi, A. 2009. Analisis pengaruh faktor pengetahuan, motivasi,dan persepsi perawat tentang supervisi kepala ruang terhadappelaksanaan dokumentasi asuhan keperawatan di ruang rawat inap RSUD Kelet Provinsi Jawa Tengah di Jepara.tesis

9. Potter, P. 2010. Fundamental Of Nursing. Jakarta: Salemba Medika.

10. Putra. 2016 . Hubungan persepsi perawat tentang karakteristik pekerjaan dengan kepatuhan dalam pendokumentasian keperawatan.tesis

11. PPNI. 2016. Standar Diagnosa Keperawatan Indonesia. Jakarta: Dewan Pengurus Pusat PPNI.

12. Rahayu. 2006. Aplikasi dan Analisis Multivariat. Jakarta: Kencana

13. Rekam Medik Pasien. 2018. data rekam medik RSU B denpasar bali.

14. Subyantoro, Arif. 2009. Karakteristik Indiviidu, Karakteristik Pekerjaan, Karakteristik Organisasi Dan Kepuasan Yang Dimediasi Oleh Motivasi Kerja. Jurnal Aplikasi Manajemen.

15. Sugiyono. 2014. metode penelitian manajemen. bandung: Alfabet.

16. Sukawana, I. W. 2008. Pengantar Statistik Untuk Perawat. Denpasar. Jurusan Keperawatan Poltekes Denpasar 